\title{
Hazardous waste and health impact: a systematic review of the scientific literature
}

\author{
L. Fazzo ${ }^{1 *}$ (D) F. Minichilli ${ }^{2}$, M. Santoro ${ }^{2}$, A. Ceccarini ${ }^{3}$, M. Della Seta ${ }^{3}$, F. Bianchi ${ }^{2}$, P. Comba ${ }^{1}$ and M. Martuzzi ${ }^{4}$
}

\begin{abstract}
Waste is part of the agenda of the European Environment and Health Process and included among the topics of the Sixth Ministerial Conference on Environment and Health. Disposal and management of hazardous waste are worldwide challenges. We performed a systematic review to evaluate the evidence of the health impact of hazardous waste exposure, applying transparent and a priori defined methods. The following five steps, based on pre-defined systematic criteria, were applied. 1. Specify the research question, in terms of "Population-ExposureComparators-Outcomes" (PECO). Population: people living near hazardous waste sites; Exposure: exposure to hazardous waste; Comparators: all comparators; Outcomes: all diseases/health disorders. 2. Carry out the literature search, in Medline and EMBASE. 3. Select studies for inclusion: original epidemiological studies, published between 1999 and 2015, on populations residentially exposed to hazardous waste. 4. Assess the quality of selected studies, taking into account study design, exposure and outcome assessment, confounding control. 5. Rate the confidence in the body of evidence for each outcome taking into account the reliability of each study, the strength of the association and concordance of results.

Fifty-seven papers of epidemiological investigations on the health status of populations living near hazardous waste sites were selected for the evidence evaluation. The association between 95 health outcomes (diseases and disorders) and residential exposure to hazardous waste sites was evaluated. Health effects of residential hazardous waste exposure, previously partially unrecognized, were highlighted. Sufficient evidence was found of association between exposure to oil industry waste that releases high concentrations of hydrogen sulphide and acute symptoms. The evidence of causal relationship with hazardous waste was defined as limited for: liver, bladder, breast and testis cancers, non-Hodgkin lymphoma, asthma, congenital anomalies overall and anomalies of the neural tube, urogenital, connective and musculoskeletal systems, low birth weight and pre-term birth; evidence was defined as inadequate for the other health outcomes. The results, although not conclusive, provide indications that more effective public health policies on hazardous waste management are urgently needed. International, national and local authorities should oppose and eliminate poor, outdated and illegal practices of waste disposal, including illegal transboundary trade, and increase support regulation and its enforcement.
\end{abstract}

Keywords: Waste, Hazardous waste, Health, Cancer, Disease, Congenital anomalies, Review

\footnotetext{
* Correspondence: lucia.fazzo@iss.it

'Department of Environment and Health, Unit of Environmental and Social

Epidemiology, Istituto Superiore di Sanità, viale Regina Elena 299, 00161

Rome, Italy

Full list of author information is available at the end of the article
} 


\section{Background}

This paper presents a systematic review of the available literature on health effects of the residence in the vicinity of hazardous waste sites. Our aim was to evaluate the evidence of the association between exposure to hazardous waste and health outcomes.

The term "hazardous" waste is variously applied in different countries, loosely defining non-household waste that includes hazardous chemicals. In our search literature, we included the terms "hazardous", "toxic", "industrial" waste, excluding the papers about municipal landfills, which have no records of hazardous materials, incinerators, e-waste and radioactive waste disposals. The present review does not consider occupational studies.

Waste, and in particular hazardous waste, is one of the priority areas for the Member States of the World Health Organization (WHO) Regional Office for Europe and was in the agenda of the Sixth Ministerial Conference on Environment and Health [1].

Disposal and management of waste are world-wide problems. Poor, outdated and illegal practices of urban and hazardous waste disposal affect local communities virtually in all countries; this includes illegal transboundary trade, mostly from industrialized countries [2]. The burden of diseases of waste-related exposures in middlelow income countries is increasing and not sufficiently recognized [3].

Several investigations indicate poor and illegal waste management as the most important world-wide cause of contamination of soil and groundwater.

In January 2007, the US Environmental Protection Agency's National Priority List (NPL) included 1240 hazardous waste sites, comprising 157 federal facilities. The Environmental Protection Agency (EPA) estimated 41 million people were living within a 4-mile radius of an NPL site in 2007. Waste storage/treatment/disposal are the main activities in the 1684 present or past NPL sites across the country (31.5\%), followed by manufacturing and industries (30.8\%) [4].

In Europe, in 2014, 342,000 contaminated sites were identified (5.7 per 10,000 inhabitants). On the basis of the data provided by 33 countries, in 2011 the activities which contributed most to soil and groundwater contamination were waste disposal, including municipal and industrial waste (about $38 \%$ of the sites), and industrial and commercial activities (mining, oil extraction and production, power plants - about $34 \%$ of the contaminated sites) [5].

This type of data is less frequently available in middlelow income countries. In seven Asian countries, 679 areas were identified as contaminated by hazardous waste. Of these, 169 sites were polluted by lead resulting in an estimated 245,949 0-4 years old children exposed to lead. The estimated levels of exposure might be sufficient to generate acute and chronic adverse effects, such as a decrease in Intelligence Quotient (IQ) [6]. Chatman-Stephens and colleagues analyzed 373 hazardous waste sites in three Asian countries (India, Indonesia, Philippines) and estimated approximately 9 million people to be at risk; adding another estimated 43 million people at risk from unscreened sites to the exposed population, 4 million DALYs (disability-adjusted life years) associated with hazardous waste sites were estimated as the impact [7].

In Africa, where WHO estimates that $1 / 3$ of the burden of disease is attributable to environmental risk factors [8], hazardous waste have been included among the first three main such factors [9]; domestic and hazardous waste management is of particular concern [10]. In most African cities, less than $20 \%$ of urban waste is disposed of in landfills. The remaining waste ends up in illegal dumps [11]. Africa is also one of the main destinations of illegal transboundary trade of urban and hazardous waste from industrialized countries [2].

In this context, waste from end-of-life electrical and electronic equipment, so called "e-waste", is especially important. E-waste contains recognized hazardous substances that may be directly released or generated after disposal or during the recycling process. Unsafe recycling techniques in middle-low income African and Asian countries, where $75 \%$ and $80 \%$ of respectively EU- and USA-produced total e-waste is illegaly exported, involve high risks, primarly for workers, who are often children and women [12].

In recent years, investigations reporting a wide spectrum of health risks for local populations living in the areas surrounding hazardous waste dumping sites have been published. Still, an up-to-date evaluation of the evidence of the association between adverse health effects and hazardous waste is not available.

In 2000, a review of hazardous waste reported that the evidence of a causal relationship with cancers "is still weak", especially with regard to specific cancers reported in more than one study: leukemia, bladder, lung and stomach cancers [13]. A relationship was suggested with adverse pregnancy outcomes, i.e. low birth weight, total birth defects and cardiac, musculoskeletal and central nervous system defects. However, the authors considered that the studies were still too few to draw conclusions regarding causality.

In 2007, a WHO report on waste and health concluded: "Despite the methodological limitations, the scientific literature on the health effects of landfills provides some indication of the association between residing near a landfill site and adverse health effects. The evidence, somewhat stronger for reproductive outcomes than for cancer, is not sufficient to establish the causality of the association. However, in consideration of the large proportion of population potentially exposed to landfills 
in many European countries and of the low power of the studies to find a real risk, the potential health implications cannot be dismissed". The Report deals with landfills at large and not specifically with hazardous waste management; some case-studies, though, address this issue and recommendations about study design are provided [14].

A review on cancer epidemiology studies of populations resident close to toxic waste sites concluded that available studies provided valid hypotheses, but cannot determine whether residence near toxic waste sites causes an increased cancer risk [15].

A subsequent review of the literature on health impact of municipal waste management assessed the evidence of association with urban waste landfills as limited for total, neural tube and genitourinary birth defects, and low birth weight [16]. Consistent conclusions were reached by Mattiello and colleagues [17].

In this context, a systematic review is presented to evaluate the evidence of health impact of hazardous waste exposure, applying a priori defined criteria.

\section{Methods}

As recently recommended by authoritative agencies, such as the US EPA and WHO [18-21], established methods and selection criteria defined a priori were applied.

A five-step process, as described by Woodruff, was followed: 1 . Specify the research question; 2. Carry out the literature search, specifying the search strategy with sufficient detail so that it can be reproduced; 3 . Select studies for inclusion, analyzing their compliance with a priori defined criteria; 4 . Assess the quality of individual selected studies; 5 . Rate the confidence in the body of evidence for each outcome [20]. In detail:

1. The research question was formulated in terms of "Population-Exposure-Comparators-Outcomes" (PECO): Population: people living near hazardous waste sites; Exposure: exposure to hazardous waste; Comparators: all comparators; Outcomes: all diseases/health disorders.

2. Search strategy: the search was conducted in Medline and EMBASE, on STN International (Information Service for research and patent information: stnk.fiz-karlsruhe.de), using both textwords (Table 1) and descriptors (Table 2) based on the above PECO question. Boolean operators were used to combine exposure and outcome terms, as reported in the tables. The search was limited to the articles published in the 1999-2015 period, i.e. after those considered in the review by Vrijheid et al. [13].

3. Select studies for inclusion. Original epidemiological studies on populations residentially exposed to hazardous waste were considered; the criteria for inclusion of articles in the review were defined a
Table 1 Text-word searching in Medline and EMBASE

\begin{tabular}{ll}
\hline Search & Text words \\
\hline \#1 Exposure & (INDUSTR? OR ILLEGAL OR HAZARDOUS OR TOXIC) (W) \\
& (WAST? OR LANDFILL OR DUMP?) \\
\#2 Health & (RESPIRATORY OR CARDIOVASCULAR OR URINARY OR \\
outcomes & KIDNEY) OR (ADVERSE EFFECT OR HEALTH EFFECT OR \\
& HEALTH IMPACT) OR (CANCER OR TUMOR OR \\
& NEOPLASM) OR (CONGENITAL OR REPRODUCT? OR \\
& BIRTH OR NEONATAL) OR (BIRTH? OR REPROD? OR \\
& TERATO?) OR (DIABETE? OR THYROID?) OR (ACUTE \\
& EFFECT) OR (ACUTE TOXIC?) \\
\#3 & (BIOMONITOR? OR BIO(W) MONITOR?) \\
Biomonitoring & \\
\hline
\end{tabular}

priori. Exclusion criteria based on types of waste were defined: urban waste (landfills/incinerators), e-waste and radioactive waste; the latter two because of their peculiarities (potentially released agents and affected sub-populations). Reviews and economic evaluations were not included in the evidence evaluation, but considered subsequently for discussion purposes. Biomonitoring and toxicological studies were not considered as part of the main body of primary evidence, but were retained for interpreting and evaluating the findings of epidemiological investigations.

Each study identified in the initial literature search was assessed for inclusion independently by two investigators. Studies were included or excluded upon

Table 2 MeSH (Medline) and EMtree (EMBASE) descriptors used in search strategy

\begin{tabular}{|c|c|}
\hline \multicolumn{2}{|l|}{ Search } \\
\hline \multirow[b]{2}{*}{ \#1 Exposure } & MeSH descriptors \\
\hline & $\begin{array}{l}\text { (HAZARDOUS WASTE + NT/CT) AND } \\
\text { ((ENVIRONMENTAL HEALTH + NT/CT) OR } \\
\text { ENVIRONMENTAL EXPOSURE + NT/CT)) }\end{array}$ \\
\hline \#2 Health outcomes & $(\text { EPIDEMIOLOGY/CT) })^{\mathrm{a}}$ OR (MORTALITY/CT) \\
\hline \multirow[t]{2}{*}{ \#3 } & $\# 1$ AND \#2 \\
\hline & EMtree descriptors \\
\hline \#1 Exposure & *HAZARDOUS WASTE + NT/CT \\
\hline \#2 Health outcomes & EPIDEMIOLOGY + NT/CT \\
\hline \#3 & $\# 1$ AND \#2 \\
\hline \multicolumn{2}{|c|}{$\begin{array}{l}\text { "Epidemiology: used with human and veterinary diseases for the distribution } \\
\text { of disease, factors which cause disease, and the attributes of disease in } \\
\text { defined populations; includes incidence, frequency, prevalence, endemic and } \\
\text { epidemic outbreaks; also surveys and estimates of morbidity in geographic } \\
\text { areas and in specified populations. Used also with geographical headings for } \\
\text { the location of epidemiologic aspects of a disease. Excludes mortality for } \\
\text { which "mortality" is used. (National Library of Medicine) } \\
\text { 'Mortality: Used with human and veterinary diseases for mortality statistics. } \\
\text { For deaths resulting from various procedures statistically but for a death } \\
\text { resulting in a specific case, use FATAL OUTCOME, not /mortality. (National } \\
\text { Library of Medicine) }\end{array}$} \\
\hline
\end{tabular}


concordant assessment; a third investigator's opinion was used in case of discordant assessment.

4. Assess the quality of individual studies. The full team of investigators established the reliability of each study. This step involved an evaluation of the possible role of chance (random error) and bias (systematic error), arising from flawed exposure and outcome assessment, confounding factors or study design leading to selection bias. A qualitative rating of these items (exposure and outcome assessment, confounding control) was included in the assessment and is reported in tables, with a notation ranging from " - - to " + +". The overall assessment was not univocally determined by these ratings, but reflected a final expert judgement of each paper's quality.

This evaluation was performed individually by one investigator per paper and, subsequently, discussed by the overall group. The reliability of each study was defined in 5 classes, from low (1) to high (5).

5. Rate the strength of the body of evidence, for each outcome. The evaluation of the evidence of association between each health outcome and hazardous waste exposure was estimated taking into account the reliability of each study, the magnitude and the accuracy of the estimated association, and the concordance between study findings. The evidence was rated in three grades: Sufficient/ Limited/Inadequate, partly derived from the approach used by the International Agency for Research on Cancer (IARC) Monographs [22], but specifically defined, as follows.

Sufficient: More than one study of high or moderate/high quality (rated 5-4) report positive findings with strong (high values of relative risk) and precise, overall consistent association. Alternative explanations, in particular the role of random variability, bias, confounding factors, can be reasonably excluded. The force of association, considerations on dose-response relationship, time coherence and biological plausibility further support causality.

Limited: More than one study of high or moderate/high quality (rated 5-4) report positive findings with strong (high values of relative risk) and precise association. Among the concurring different risk estimates, the results of higher quality studies was given higher weight. A role of random variability, bias and confounding factors may not be completely excluded.

Inadequate: Less than two studies of moderate or higher quality rate (rated 5-3) report findings of risk in excess; or, there are two or more studies of moderate/ high quality, but the results in excess are not consistent and/or the associations are weak and inaccurate.

\section{Results}

Two thousand five hundred ninety three records were retrieved from MedLine and EMBASE text-word and descriptor searching; 913 of these were excluded because published before 1999 .

Of the remaining 1680 records, 1461 were excluded on the basis of title and abstract, because not responding to the a priori defined PECO question. The abstracts of the resulting 219 papers were then evaluated independently by two investigators on the basis of the inclusion criteria. The results of this first evaluation were reviewed by the full team of investigators. 167 papers of epidemiological investigations on populations living near hazardous waste sites were selected. Following a review of the full-text of each study, 110 were considered not relevant and were excluded. 57 articles were eventually selected and underwent the evaluation of the strength of evidence (Fig. 1).

Most of the selected studies reported more than one health outcome. Altogether, the association between 95 health outcomes (diseases and disorders) and residential exposure to hazardous waste sites was reported on.

Additional file 1: Table S1, Additional file 2: Table S2 and Additional file 3: Table S3 report, for each outcome,

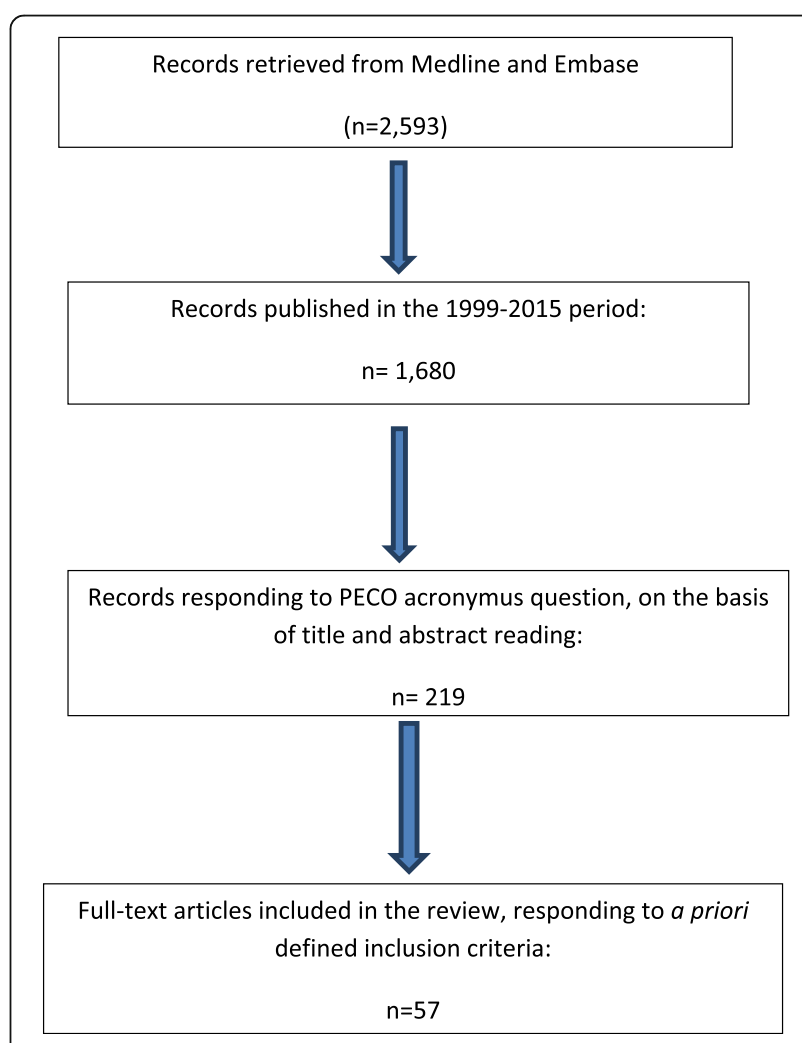

Fig. 1 Flow chart showing the literature search and screening process 
the studies' characteristics, the qualitative rating of risk of bias, a reliability assessment and the overall evidence evaluation.

As a result, the evidence of the causal association between hazardous waste related exposures and chronic and reproductive health outcomes was evaluated as: limited, for liver, breast, testis and bladder cancers, non-Hodgkin lymphoma and asthma (Additional file 1: Table S1), overall and specific congenital anomalies (urogenital, neural tube, musculoskeletal and connective system), low birth weight and pre-term birth (Additional file 2: Table S2); inadequate, for all the other health outcomes.

Studies on acute effects in populations living near illegal dump sites in Abidjan [23, 24] provided sufficient evidence of association between exposure to oil industry waste and general and neurological acute symptoms, and specifically otolaryngological, respiratory, digestive and dermatological symptoms (Additional file 3: Table S3).

\section{Discussion}

The present review considers literature pertaining sites where hazardous waste was handled without control or suitable environmental management. These practices take place both in high and low-middle income countries. However, they occur more frequently in the latter, through illegal dumping of hazardous waste, or when waste dumping took place prior to the enforcement of environmental regulations, or in countries where there is no regulation. In some cases, hazardous waste can be unknowingly present in landfills.

Rigourous methodology for systematic and a priori criteria-based reviews was used. The application of criteria of "reliability" based on risk of bias to observational studies requires some consideration. In order to evaluate the strength of study results, and their risk of bias, exposure and outcome assessment methods, confounding control and study design were considered. Most of the selected studies were ecological, a design which is generally regarded as weaker than individual-level studies, because of the so-called "ecological fallacy" (i.e., interpreting associations at the aggregated level as causality at the individual level) [25]. Ecological studies, however, have played a major role in the investigation of etiological associations of public health importance [22, 25].

The reliability of the majority of the studies were considered "moderate", primarily due to the limitations of exposure assessment based on the residence at outcome observation time. Data about the contaminants present in the waste site at the time of the study and in the surrounding residential environment was rarely available. When it was, a higher weight was assigned to the study.
Furthermore, the definition of hazardous waste limits comparability between studies. Hazardous waste includes a broad range of contaminants affecting different environmental matrices and involving several routes of exposure, depending on types of waste and hydrogeological and meteorological factors. These limitations tend to underestimate, rather than overestimate, the magnitude of health effects, thus diluting the evidence for specific types of hazardous waste exposure.

The evidence of the association between general and neurological acute symptoms, in particular those regarding otolaryngological, respiratory and digestive systems and the skin, and exposure to oil industry waste releasing high concentrations of hydrogen sulphide was evaluated as sufficient. This evaluation was based on two cross-sectional studies performed in the population resident in Abidjan near the sites where approximately 500 tons of hazardous waste was illegaly dumped and subsequently emitted hydrogen sulphid into the air [23, 24]. The two studies were evaluated respectively as being of high and moderate/high quality (rated 5-4). They consistently reported elevated relative risks, with good accuracy. Furthermore, strength of association, presence of a dose-response relationship, time coherence and biological plausibility support causality. Alternative explanations, in particular the role of random variability, systematic bias and confounding factors, can be reasonably excluded.

Contaminants emitted or released by hazardous waste might play a role for the occurrence of diseases with multi-factor etiology, however evidence of an association was limited, as in the case of liver cancer. In the abovementioned review of municipal waste management, inadequate evidence was attributed to the association between liver cancer and landfills [16]. B and C hepatitis viruses, alcohol consumption, tobacco smoking and aflatoxins are the main ascertained risk factors for liver cancer. Exposure to vinyl chloride and 1,2-dichloropropane was defined by IARC as associated with hepatic cancer with sufficient evidence. The evidence regarding the association of arsenic and its inorganic compounds, DDT, dichloromethane and trichloroethylene was defined as limited [26]. Even if $80-95 \%$ of hepatocellular carcinomas at the global level are associated with $\mathrm{B}$ or $\mathrm{C}$ hepatitis chronic viral infection [27], an interaction between chemicals and the other risk factors has been suggested, i.e. occupational exposure to vinyl chloride monomer (VCM) and hepatitis B virus infection $[28,29]$.

Hepatotoxic chemical agents can be both naturally occurring and synthetic; the latter comprise metals, aromatic and halogenated hydrocarbons, chlorinated aromatic and nitro compounds that can, to various extents, be present in or released by hazardous waste 
[29]; hepatotoxicity can be related to hepatic carcinogenicity.

Our evaluation on liver cancer was based on the results of ten articles; some of them reported the presence of organic chlorinated compounds, such as vinyl chloride [30] and beta-hexachlorocyclohexane, $\beta-\mathrm{HCH}$ [31], and of heavy metals, including arsenic [31]. Other studies $[32,33]$ regarded areas in which biomonitoring detected presence of dioxins in breast milk of women [34]. In the latter studies the synergistic effects between different risk factors, including $B$ hepatitis virus and hazardous waste contaminants, may be reasonably hypothesized.

We attributed limited evidence to the association between bladder cancer and hazardous waste on the basis of ten articles. The previous review by Porta defined the association between bladder cancer and urban waste disposals as limited [16]; another review found bladder cancer among those reported in excess in more than one study [13]. A number of agents were defined by IARC as associated with bladder cancer with sufficient evidence, including tobacco smoke, arsenic and its compunds, and occupational exposures occurring in industries involving the production and/or use of aluminum, auramine, magenta, rubber, and paint; evidence was classified as limited for occupational exposure of hairdressers and barbers, coal-tar pitch, printing processes and textile manufacturing, and, among chemical agents, for specific chloro-compounds, i.e. 4-chloroortho-toluidine and tetrachloroethylene [26]. A specific association between bladder cancer and benzo(a)pyrene was reported elsewhere [35].

Some of the ten articles on bladder cancer considered in the present review reported the presence of contaminants associated with bladder cancer in the study areas. Heavy metals in soil and groundwater, and $\beta-\mathrm{HCH}$ in blood of some residents were reported in the Sacco river areas [31]; hexachlorocyclohexanes, benzylchlorides, organic sulfur compounds, chlorobenzenes, and sodium sulfide/sulfhydrates polluted the Love Canal site [36], where a biomonitoring study reported also trichlorobenzene and dichlorobenzene contamination [37]. Dioxins were detected in biomonitoring studies in Campania waste sites [34] located in towns where increased bladder cancer risk was reported [32, 33].

Nine articles included in the present review determined the evaluation of limited evidence for the association between non-Hodgkin lymphoma (NHL) and hazardous waste: excess risks were reported in areas contaminated by organic chloro compounds, including vinyl chloride [30] and $\beta-\mathrm{HCH}$ [31], heavy metals [31] and, in Superfund sites, in areas with benzene-emitting hazardous waste sites [38]. The main known risk factors of NHL, associated with sufficient evidence according to IARC, are viral factors (Epstein-Barr virus, hepatitis C virus, HIV type1). Several chemical agents were defined as risk factors for NHL with limited evidence: benzene, ethylene oxide, 2,3,7,8-tetrachlorodibenzo-para-dioxin (TCDD), PCBs, tetrachloroethylene, trichloroethylene, polychlorophenols and their sodium salts [39].

For breast and testis cancers, the evidence was evaluated taking into account similarities in their biological characteristics. Limited evidence attributed to breast and testis cancers is based on the etiological plausibility of their relationship with endocrine disruptors (EDCs). This evaluation is corroborated by the results found for urogenital tract defects. A role of exposure to EDCs was hypothesized in incidence of breast and testis cancers and urogenital tract anomalies [40]: positive results for these outcomes in the selected studies and the possible presence of these contaminants in hazardous waste sites support the hypothesis of a causal relationship. A European casecontrol study on occupational exposure to endocrine disrupting chemicals in male breast cancer suggested a possible role of occupational exposures to oil and petroleum solvents in motor vehicle mechanics and to chemicals such as alkylphenolic compounds [41]. IARC defined as limited the association between breast cancer and the exposute to dioxins, ethylene oxide and PCBs [26].

In our review, five articles on breast cancer were considered, including the above-mentioned studies on areas with documented contamination [31, 32, 36] and an article on populations living in zip code areas near Superfund sites polluted by volatile organic compounds (including chloroethenes, chloroethanes, chloromethanes, chlorobenzenes, benzene, toluene, ethyl benzene, xylene) [42].

For testis cancer, IARC assessed limited evidence for DDT, diethylstilbestrol (exposure in utero), N,N-dimethylformamide, perfluorooctanoic acid; no agents were defined as associated with testis cancer with sufficient evidence [26]. An etiological role of exposure to endocrine disruptors in the onset of testis cancer was hypothesized [43] and suggested in some reviews [44, 45]. A possible association between endocrine disruptors and testicular cancer could be explained by the Testicular Dysgenesis Syndrome, reflecting a hormonal imbalance due to environmental or life-style factors during early fetal development $[40,46,47]$ and during puberty due to the ingestion of contaminated milk [47].

Finally, evidence of hazardous waste effects on asthma and adverse reproductive effects was considered limited. We based the evaluation for asthma on five studies considering, in particular, populations (both adults and 0-14 year old children) living near hazardous waste sites with emission of POPs (dioxins/furans, PCB, chlorinated pesticides) $[48,49]$, heavy metals and $\beta-\mathrm{HCH}[31]$ and other organic compounds [50]. 
In 2006, WHO suggested that airborne particulate matter contributes to the exacerbation of asthma based on "considerable" evidence. Atmospheric particles, including acid aerosols derived from sulfur dioxide emissions, have been linked with worsening of symptoms, reduction in lung function, increased hospital admissions for asthma and increased use of medication. The evidence that exposure to certain kinds of particulate matter (PM), such as diesel exhausts, may contribute to causing asthma in susceptible subjects has been defined as "suggestive" [51]. A Report of the US Department of Health and Human Services defined the evidence of the causal role of active and second-hand smoke, in the incidence and exacerbation of asthma as sufficient or suggestive in different subgroups of the population [52]. Therefore, it is plausible that hazardous waste emitting air pollutants might cause asthma in susceptible subjects or exacerbate asthma cases.

Diabetes and infectious respiratory diseases, for which the evidence of association with hazardous waste was evaluated as inadequate, deserve some considerations. Two studies included in our review reported consistent findings of an increased risk for diabetes. One study was carried out in an area with heavy metals in the soil and groundwater and $\beta-\mathrm{HCH}$ in dairy products, forage, soils and in blood samples of residents [31], and the other in a Superfund site with contamination by Persistent Organic Pollutants, POPs (PCBs, dioxins/furans, or chlorinated and persistent pesticides) [53]. Taking into account the high prevalence of the disease and the need to thoroughly assess the role of its many ascertained risk factors, the evaluation of the role of environmental exposures is challenging. A recent systematic review indicated a positive association between diabetes and serum concentrations of several pollutants (such as polychlorinated dibenzodioxins and dibenzofurans, PCBs, and several organochlorine pesticides) [54]. Type 2 diabetes has recently been recognized as a risk modifier for PM health effects, enhancing mortality risks associated with PM exposure [51]. The evidence of a causal association between the risk of diabetes and active smoking was defined as sufficient, with a positive dose-response relationship with the number of cigarettes smoked [52].

We evaluated as inadequate the evidence of the association of hazardous waste with "acute infections of the respiratory system, pneumonia, influenza" because of the lack of consistency between studies. However, consistent results of increased risk were reported near waste sites with air emissions of POPs [48, 49]. Taking into account the available evidence on health effects of air pollution [51], these results require further confirmation, notably in populations living near hazardous waste that emits air pollutants.

Regarding congenital anomalies (CAs), the evidence of association to hazardous waste was evaluated as limited for overall and some subgroups of CAs (i.e. urogenital, connective and musculoskeletal system and neural tube anomalies). These findings are consistent with previous reviews $[13,16,17]$. Our update confirms some limitations mainly due to the small number of studies and weak exposure assessment. As CAs are short-term latency outcomes, they are important for investigating short-term effects in polluted areas. The etiology of CA is multi-factorial, with an important role of genetic factors, and a recognized interaction between genetic and environmental factors [55] and epigenetic mechanisms; this topic deserves further investigation in order to better clarify the etiological pattern.

Since CAs are relatively rare events, affecting about 2 $3 \%$ of births, groups including several specific anomalies are usually investigated in epidemiological studies. Despite this, the reported risk estimates are often not accurate. Furthermore, the interpretation of results regarding groups of CAs with different causes is difficult and requires caution [56]. Two of the reviewed studies investigated the association between exposure to hazardous waste and hypospadias. This association is of interest since the vast majority of cases seem to have multi-factorial aetiology, with many genetic and environmental factors playing a role, in particular endocrinedisrupting chemicals [57-59]. Our results are in agreement with a recent review claiming that the literature is currently poor and does not support a conclusive judgment on environmental contaminants and congenital anomalies in the general population [60].

Among the five studies considered for pre-term birth evaluation only two were evaluated as high quality, and although the estimated risks were above unity for all the studies, none reached statistical significance, except in the study of Love Canal residents, who had a significant risk of pre-term birth compared to New York State reference rates. The overall results on pre-term birth, however, could reflect the studies' low statistical power and do not warrant an evaluation of evidence higher than limited.

The studies on low birth weight (LBW) were more numerous; among the nine studies considered, one was of high quality, reporting no significantly increased risks [61], and two were of moderate-high quality and reported statistically significant excess of risk [62, 63]. Although the body of evidence is richer than for pre-term birth, we believe that it is still not enough to upgrade the evaluation of limited evidence previously assigned by Porta (2009) [16] and Mattiello (2013) [17] for the association with landfills of urban waste.

\section{Conclusions}

The present review highlighted that there is sufficient evidence of association between exposure to oil 
industry waste releasing high concentrations of hydrogen sulphide and acute symptoms. The evidence of causal relationship with hazardous waste was defined as limited for: liver, bladder, breast and testis cancers and non-Hodgkin lymphoma. Among non-neoplastic diseases, asthma was found to be related to hazardous waste with limited evidence. We evaluated as limited the evidence of the association between the exposure to hazardous waste and adverse birth outcomes, including low birth weight, pre-term birth, congenital anomalies overall and anomalies of the urogenital, connective and musculoskeletal systems. The evidence of a causal relationship was defined as inadequate for most other health outcomes.

The available evidence of the health effects of specific contaminants present in some hazardous waste corroborates our evaluation. In particular, drawing from the evidence described in the previous section: persistent organic pollutants, in particular benzene and those chlorinated, i.e. PCBs and dioxins (for liver, bladder and breast cancers, NHL and asthma), heavy metals, i.e. arsenic and its compounds (for NHL, liver and bladder cancers) and EDCs (for testis and breast cancers, CAs).

These data confirm that hazardous waste, if not suitably managed, might cause adverse health effects on populations living near the sites where they are dumped or processed. The contamination of different environmental matrices, including food, water, soil and air, represents a health risk for these populations. A strong contrast to illegal trade and the deployment of sound management practices is warranted as a priority - no further evidence is needed.

In several instances, however, further investigation is warranted to fill important knowledge gaps: in particular, population studies analysing different pathways of exposure, taking into account the characteristics of the site and the contaminants present in each waste site, might provide useful information. Acute respiratory diseases, diabetes and childhood neurological disorders are of particular interest, also in consideration of the strong indications that environmental exposures to EDCs and potential EDCs can cause cognitive and behavioural deficits in humans [40].

The results of our review, although not conclusive, provide indications that public health policies on hazardous waste management are urgently needed. International, national and local authorities should oppose and eliminate poor, outdated and illegal practices of waste disposal (including illegal transboundary trade), which still affect some communities in industrialized and middle-low income countries, and implement and enforce regulation. Compliance with the Basel Convention on the Control of Transboundary Movements of Hazardous Wastes and their Disposal is necessary to prevent high exposures and consequent health effects, particularly among the vulnerable and the poor [64].

\section{Additional files}

Additional file 1: Table S1. Hazardous waste: general population mortality and morbidity [65-87] (XLSX $51 \mathrm{~kb}$ )

Additional file 2: Table S2. Hazardous waste: birth outcomes [88-105] (XLSX $30 \mathrm{~kb}$ )

Additional file 3: Table S3 Hazardous waste: acute effects (XLSX 12 kb)

\section{Acknowledgements}

The Authors thank Anna Bastone, of the Unit of Enviornmental and Social Epidemiology of Istituto Superiore di Sanità, for her contribution in editorial assistance.

\section{Funding}

The publication costs will be borne by the Department of Environment and Health of the Istituto Superiore di Sanità, Rome, Italy.

\section{Availability of data and materials}

All data generated or analysed during this study are included in this published article [and its Additional files].

\section{Authors' contributions}

LF: made substantial contributions to the conception and design of the work, the acquisition, analysis and interpretation of data, the development of the draft and review of the manuscript. FM: made substantial contributions to the acquisition, analysis and interpretation of data, and review of the manuscript. MS: made substantial contributions to the acquisition, analysis and interpretation of data, and review of the manuscript. AC: made substantial contributions to the design and performance of the literature search, and review of the manuscript. MDS: made substantial contributions to the design of the literature search, and review of the manuscript. FB: made substantial contributions to the conception the work, analysis and interpretation of data, and review of the manuscript. PC: made substantial contributions to the conception the work, analysis and interpretation of data, and review of the manuscript. MM: made substantial contributions to the conception the work, interpretation of data, and review of the manuscript. All authors read and approved the final manuscript.

Ethics approval and consent to participate Not applicable.

Consent for publication

Not applicable.

\section{Competing interests}

The authors declare that they have no competing interests.

\section{Publisher's Note}

Springer Nature remains neutral with regard to jurisdictional claims in published maps and institutional affiliations.

\section{Author details}

${ }^{1}$ Department of Environment and Health, Unit of Environmental and Social Epidemiology, Istituto Superiore di Sanità, viale Regina Elena 299, 00161 Rome, Italy. ${ }^{2}$ Institute of Clinical Physiology, Unit of Environmental epidemiology and disease registries, National Research Council, Via Giuseppe Moruzzi 1, 56124 Pisa, Italy. ${ }^{3}$ Documentation Service, Istituto Superiore di Sanità, viale Regina Elena 299, 00161 Rome, Italy. ${ }^{4}$ Centre for Environment and Health, World Health Organization - Regional Office for Europe, Platz der Vereinten Nationen 1, D-53113 Bonn, Germany. 
Received: 9 January 2017 Accepted: 26 September 2017 Published online: 11 October 2017

\section{References}

1. World Health Organization. Waste and human health: evidence and needs. WHO Meeting Report: 5-6 November 2015. Bonn, Germany. Copenhagen: WHO Regional Office for Europe; 2016.

2. Marsili D, Fazzo L, Comba P. Health risks from hazardous waste disposal: the need for international scientific cooperation. Eur J Oncol. 2009;14:151-9.

3. Landrigan PJ, Wright RO, Cordero JF, Eaton DL, Goldstein BD, Hennig B, et al. The NIEH Superfund Research Program: 25 years of translational research for public health. Environ Health Perspect. 2015;123:909-18. doi:10.1289/ehp.1409247.

4. Pohl HR, Tarkowski S, Buczynska A, Fay M, De Rosa CT. Chemical exposures at hazardous waste sites: experiences from the United States and Poland. Environ Tox and Pharmacology. 2008;25:283-91. doi:10.1016/j.etap.2007.12.005.

5. van Liedekerke M, Prokop G, Rabl-Berger S, Kibblewhite M, Louwagie G. JRC Reference Reports. Progress in the management of Contaminated Sites in Europe. Joint Research Centre. European Commission. Publications Office of the European Union, Luxembourg; 2014. doi:10.2788/4658.

6. Caravanos J, Chatham-Stephens K, Bret E, Landrigan PJ, Fuller R. The burden of disease from pediatric lead exposure at hazardous waste sites in 7 Asian countries. Environ Research. 2013;120:119-25. doi:10.1016/j.envres.2012.06.006.

7. Chatman-Stephens K, Caravanos J, Ericson B, Sunga-Amparo J, Susilorini B, Sharma $\mathrm{P}$, et al. Burden of disease from toxic waste sites in India, Indonesia, and the Philippines in 2010. Environ Health Perspect. 2013;121:791-6. doi:10. 1289/ehp.1206127.

8. Prüss-Üstin A, Corvalán C. Preventing disease through healthy environments. Towards an estimate of the environmental burden of disease. Geneva: World Health Organization; 2006.

9. McCormack VA, Schuz J. Africa's growing cancer burden: environmental and occupational contribution. Cancer Epid. 2012;36:1-7. doi:10.1016/j.canep.2011.09.005.

10. Nweke OC, Sanders WH III. Modern environmental health hazards: a public health issue of increasing significance in Africa. Env Health Persp. 2009;117:863-70. doi:10.1289/ehp.0800126.

11. Achankeng E. Globalization, Urbanization and Municipal Solid Waste Management in Africa. In: Proceedings of the African Studies Association of Australasia and the Pacific 26th Annual Conference. Adelaide: Africa on a Global Stage: Politics, History, Economics and Culture; 2003. http://www. afsaap.org.au/assets/achankeng.pdf. Accessed 3 Oct 2017.

12. Perkins DN, Drisse BMN, Nxele T, Sly PD. E-Waste: a global hazard. Ann Glob Health. 2014;80:286-95. doi:10.1016/j.aogh.2014.10.001.

13. Vrijheid M. Health Effects of residence near hazardous waste landfill sites: a review of epidemiologic literature. Environ Health Perspect. 2000;108(suppl 1):101-12.

14. World Health Organization. Population health and waste management: scientific data and policy options. Report of a WHO workshop. Rome, Italy, 29-30 March 2007. Copenhagen: WHO Regional Office for Europe; 2007.

15. Russi MR, Jonathan BB, Cullen MR. An examination of cancer epidemiology studies among populations living close to toxic waste sites. Environ Health. 2008;7:32. doi:10.1186/1476-069X-7-32

16. Porta D, Milani S, Lazzarino Al, Perucci CA, Forastiere F. Systematic review of epidemiological studies on health effects associated with management of solid waste. Environ Health. 2009;8:60. doi:10.1186/1476-069X-8-60.

17. Mattiello A, Chiodini P, Bianco E, Forgione N, Flammia I, Gallo C, et al. Health effects associated with the disposal of solid waste in landfills and incinerators in populations living in surrounding areas: a systematic review. Int J Public Health. 2013:58:725-35. doi:10.1007/s00038-013-0496-8.

18. Barrett JR. The Navigation Guide. Systematic review for the environmental health sciences. Environ Health Persp. 2014;122(10):A283. doi:10.1289/ehp.122-A283

19. Johnson PA, Sutton P, Atchley DS, Koustas E, Lam J, Sen S, et al. The Navigation Guide - Evidence-based medicine meets environmental health: systematic review of human evidence for PFOA effects on fetal growth. Environ Health Persp. 2014;122(10):1028-39. doi:10.1289/ehp.1307893.

20. Woodruff TJ, Sutton P. The Navigation Guide systematic review methodology: a rigorous and transparent method for translating environmental health science into better health outcomes. Environ Health Persp. 2014;122(10):1007-14. 10.1289/ehp.1307175.

21. World Health Organization. WHO Handbook for Guideline Development. In: World Health Organization; 2014

22. International Agency for Research on Cancer. IARC Monographs on the evaluation of carcinogenic risks to humans. Preamble. In: Lyon: International Agency for Research on Cancer, vol. 2006. (Last update, September 2015).

23. Dongo K, Tiembré I, Koné Blaise A, Zurbrugg C, Odermatt $P$, Tanner $M$, et al. Exposure to toxic waste containing high concentrations of hydrogen sulphide illegally dumped in Abidjan, Cote d'Ivoire. Environ Sci Pollut Res Int 2012:19(8):3192-9. doi:10.1007/s11356-012-0823-2.

24. Kouassi B, Horo K, Gode C, Ahui B, Kouassi MN, Koffi N, et al. Clinical manifestations in patients exposed to an environmental toxic accident (Abidjan, Ivory Coast 2006). Rev Mal Respir. 2015;32(1):38-47. doi:10.1016/j. rmr.2014.01.015. [In French]

25. Rushton $L$, Elliott $P$. Evaluating evidence on environmental health risks. $\mathrm{Br}$ Med Bull. 2003;68(1):113-28. doi:10.1093/bmb/ldg020.

26. International Agency for Research on Cancer. List of classification by cancer sites with sufficient or limited evidence in humans, Volumes 1 to 117. Last update 24 June 2016. https://monographs.iarc.fr/ENG/Classification/Table4. pdf. Accessed 3 Oct 2017.

27. London WT, McGlynn K. Liver Cancer. In: Shottenfeld D, Fraumeni JF, editors. Cancer Epidemiology and Prevention. 3rd ed. New York: Oxford University Press; 2006.

28. Mastrangelo G, Fedeli U, Fadda E, Valentini F, Agnesi R, Magarotto G, et al. Increased risk of hepatocellular carcinoma and liver cirrhosis in vinyl chloride workers: synergistic effetcs of occupational exposure with alcohol intake. Environ Health Perspect. 2004;112(11):1188-92. doi:10.1289/ehp.6972.

29. Johnson D, Groopman JD. Toxic liver disorders. In: Rom W, Markowitz S, editors. Environmental and Occupational Medicine. Philadelphia: Lippincott Williams \& Wilkins; 2007. p. 789-99.

30. Pasetto R, Ranzi A, De Togni A, Ferretti S, Pasetti P, Angelini P, et al. Cohort study of residents of a district with soil and groundwater industrial waste contamination. Ann Ist Super Sanita. 2013:49(4):354-7. doi:10:4415/ANN_13 0406

31. Fantini F, Porta D, Fano V, De Felip E, Senofonte O, Abballe A et al. Epidemiologic studies on the health status of the population living in the Sacco River Valley. Epidemiol Prev 2012;36(5) Suppl 4:44-52. [in Italian]

32. Fazzo L, Belli S, Minichilli F, Mitis F, Santoro M, Martina L, et al. Cluster analysis of mortality and malformations in the Provinces of Naples and Caserta (Campania Region). Ann Ist Super Sanita. 2008;44(1):99-111.

33. Martuzzi M, Mitis F, Bianchi F, Minichilli F, Comba P, Fazzo L. Cancer mortality and congenital anomalies in a region of Italy with intense environmental pressure due to waste. Occup Environ Med. 2009;66(11):72532. doi:10.1136/oem.2008.044115.

34. Giovannini A, Rivezzi G, Carideo P, Ceci R, Diletti G, Ippoliti C, et al. Dioxins levels in breast milk of women living in Caserta and Naples: assessment of environmental risk factors. Chemosphere. 2014;94:76-84. doi:10.1016/j.chemosphere.2013.09.017.

35. Environmental Protection Agency US. (USEPA). Toxicological review of benzo[a]pyrene (CASRN 50-32-8). In: Support of summary information on the Integrated Risk Information System (IRIS) EPA/635/R-14/312a. External review draft; 2013. http:ofmpub.epa.gov/eims/eimscomm.getfile?p_ download_id=520493. Accessed 24 Nov 2016.

36. Gensburg Lenore J, Pantea C, Kielb C, Fitzgerald E, Stark A, Kim N. Cancer incidence among former Love Canal residents. Environ Health Perspect. 2009;117(8):1265-71. https://doi.org/10.1289/ehp.0800153.

37. Kielb $\mathrm{CL}$, Pantea $\mathrm{Cl}$, Gensburg $L$, Jansing $\mathrm{RL}$, Hwang $\mathrm{SA}$, Stark $\mathrm{AD}$, Fitzgerald EF. Concentrations of selected organochlorines and chlorobenzenes in the serum of former Love Canal residents, Niagara Falls. New York Environ Res. 2010;110(3):220-5. doi10.1016/j.envres.2009.11.004

38. Boberg E, Lessner L, Carpenter DO. The role of residence near hazardous waste sites containing benzene in the development of hematologic cancers in upstate New York. Int J Occup Med Environ Health. 2011;24(4):327-38. doi10.2478/s13382-011-0037-8

39. Cogliano VJ, Baan R, Straif K, Grosse Y, Lauby-Secretan B, El Ghissassi F. et al. Preventable exposure associated with human cancers. J Natl Cancer Inst 2011; 103:1827-1839. doi:10.1093/jnci/djr483.

40. Bergman A, Heindel JJ, Jobling S, Kidd KA, Zoeller RT, editors. State of the science of endocrine disrupting chemicals - 2012. Geneva: United Nations Environment Programme and World Health Organization; 2013 www who. int/ceh/publications/endocrine/en. Accessed 3 Oct 2017. 
41. Villeneuve S, Cyr D, Lynge E, Orsi L, Sabroe S, Merletti F, et al. Occupation and occupational exposure to endocrine disrupting chemicals in male breast cancer: a case-control study in Europe. Occup Environ Med. 2010;67: 837-44. doi10.1136/oem.2009.052175.

42. Lu X, Lessner L, Carpenter DO. Association between hospital discharge rate for female breast cancer and residence in a zip code containing hazardous waste sites. Environ Res. 2014;134:375-81. doi10.1016/j.envres.2014.07.005.

43. Sarma AV, McLaughlin JC, Schottenfeld D. Testicular Cancer. In: Shottenfeld D, Fraumeni JF, editors. Cancer. Epidemiology and Prevention. 3rd ed. New York: Oxford University Press; 2006.

44. Garner MJ, Turner MC, Ghadirian P, Krewski D. Epidemiology of testicular cancer: an overview. Int J Cancer. 2005;116:331-9. doi10.1002/ijc.21032.

45. Garner MJ, Turner MC, Ghadirian P, Krewski D, Wade M. Testicular cancer and hormonally active agents. J Toxicol Environm Health. 2008;11:260-75. doi:10.1080/10937400701873696.

46. Martin OV, Shialis T, Lester JN, Scrimshaw MD, Boobis AR, Voulvoulis N. Testicular dysgenesis syndrome and the estrogen hypothesis: a quantitative meta-analysis. Environ Health Perspect. 2008;116:149-57. doi:10.1289/ehp.10545.

47. Richiardi L, Pettersson A, Akre O. Genetic and environmentalrisk factors for testicular cancer. Int J Androl. 2007;30:230-41. doi:10.1111/j.1365-2605.2007.00760.x.

48. Ma J, Kouznetsova M, Lessner L, Carpenter DO. Asthma and infectious respiratory disease in children-correlation to residence near hazardous waste sites. Paediatr Respir Rev. 2007;8(4):292-8. doi:10.1016/j.prrv.2007.07.009.

49. Carpenter DO, Ma J, Lessner L. Asthma and infectious respiratory disease in relation to residence near hazardous waste sites. Ann N Y Acad Sci. 2008; 1140:201-8. doi:10.1196/annals.1454.000.

50. Pukkala $\mathrm{E}$, Ponka A. Increased incidence of cancer and asthma in houses built on a former dump area. Environ Health Perspect. 2001;109(11):1121-5.

51. World Health Organization. Air quality guidelines. Global update 2005. Denmark: WHO Regional Office for Europe. p. 2006.

52. U.S. Department of Health and Human Services. The health consequences of smoking 50 years of progress: a report of the surgeon general. Atlanta: $U$. S. Department of Health and Human Services, Centers for Disease Control and Prevention, National Center for Chronic Disease Prevention and Health Promotion, Office on Smoking and Health; 2014.

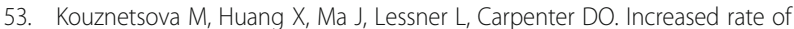
hospitalization for diabetes and residential proximity of hazardous waste sites. Environ Health Perspect. 2007;115(1):75-9. doi:10.1289/ehp.9223.

54. Jaacks LM, Staimez LR. Association of persistent organic pollutants and nonpersistent pesticides with diabetes and diabetes-related health outcomes in Asia: a systematic review. Environ Int. 2015;76:57-70. doi:10.1016/j.envint.2014.12.001.

55. Dolk H. Epidemiologic approaches to identifying environmental causes of birth defects. Am J Med Genet. 2004;125C:4-11. doi:10.1002/ajmg.c.30000.

56. Dolk H, Vrijheid M. The impact of environmental pollution on congenital anomalies. Br Med Bull. 2003;68:25-45. doi:10.1097/MED.0000000000000063.

57. van der Zanden LF, van Rooij IA, Feitz WF, Franke B, Knoers NV, Roeleveld N. Aetiology of hypospadias: a systematic review of genes and environment. Hum Reprod Update. 2012;18:260-83. doi:10.1093/humupd/dms002.

58. Shih EM, Graham JM Jr. Review of genetic and environmental factors leading to hypospadias. Eur J Med Genet. 2014;57:453-63. doi10.1159/000441988.

59. Thorup J, Nordenskjöld A, Hutson JM. Genetic and environmental origins of hypospadias. Curr Opin Endocrinol Diabetes Obes. 2014;21(3):227-32. doi:10.1097/MED.0000000000000063.

60. Foster WG, Evans JA, Little J, Arbour L, Moore A, Sauve R, et al. Human exposure to environmental contaminants and congenital anomalies: a critical review. Clin Rev Toxicol. 2016:11-26. doi:10.1080/10408444.2016.1211090.

61. Austin AA, Fitzgerald EF, Pantea Cl, Gensburg LJ, Kim NK, Stark AD, et al. Reproductive outcomes among former Love Canal residents, Niagara Falls, New York. Environ Res. 2011;111:693-701. doi:10.1016/j.envres.2011.04.002.

62. Elliott P, Briggs D, Morris S, de Hoogh C, Hurt C, Jensen TK, et al. Risk of adverse birth outcomes in populations living near landfill sites. BMJ. 2001;323(7309):363-8.

63. Gilbreath S, Kass PH. Adverse birth outcomes associated with open dumpsites in Alaska Native Villages. Am J Epidemiol. 2006;164(6):518-28. doi:10.1093/aje/kwj241

64. UNEP. Basel Convention on the control of transboudary movements of hazardous wastes and their disposal. Basel Convention: Châtelaine; 1992. http://www.basel.int/portals/4/basel\%20convention/docs/text/ baselconventiontext-e.pdf. Accessed 3 Oct 2017.
65. Altavista P, Belli S, Bianchi F, Binazzi A, Comba P, Del Giudice R. et al. Cause specific mortality in a district of Campania Region with a high number of waste dump sites Epidemiol Prevention 2004; 28(6):311-321. [in Italian].

66. Comba P, Bianchi F, Fazzo L, Martina L, Menegozzo M, Minichilli F, et al. Cancer mortality in an area of Campania (Italy) characterized by multiple toxic dumping sites. Ann N Y Acad Sci. 2006;1076:449-61.

67. Gensburg LJ, Pantea C, Fitzgerald E, Stark A, Hwang S, Kim N. Mortality among former Love Canal residents. Environ Health Perspect. 2009;117(2): 209-16. doi:10.1289/ehp.11350.

68. Kearney G. A procedure for detecting childhood cancer clusters near hazardous waste sites in Florida. J Environ Health. 2008;70(9):29-34.

69. Fazzo L, De Santis M, Mitis F, Benedetti M, Martuzzi M, Comba P, et al. Ecological studies of cancer incidence in an area interested by dumping waste sites in Campania (Italy). Ann Ist Super Sanita. 2011;47(2):181-91. doi:10.4415/ANN_11 02 10.

70. Garcia-Perez J, Fernandez-Navarro P, Castello A, Lopez-Cima MF, Ramis R, Boldo $E$, et al. Cancer mortality in towns in the vicinity of incinerators and installations for the recovery or disposal of hazardous waste. Environ Int. 2013:51:31-44. doi:10.1016/j.envint.2012.10.003.

71. Fazzo L, Minichilli F, Pirastu R, Bellino M, Falleni F, Comba P, et al. A meta-analysis of mortality data in Italian contaminated sites with industrial waste landfills or illegal dumps. Ann Ist Super Sanita. 2014; 50(3):278-85. doi:10.4415/ANN_14_03_10.

72. Senior K, Mazza A. Italian "Triangle of death" linked to waste crisis. Lancet Oncol. 2004:5(9):525-7.

73. Minichilli F, Bartolacci S, Buiatti E, Pallante V, Scala D, Bianchi F. A study on mortality around six municipal solid waste landfills in Tuscany Region. Epidemiol Prev. 2005;29(5-6 Suppl):53-6. [in Italian]

74. Jarup L, Briggs D, de Hoogh C, Morris S, Hurt C, Lewin A, et al. Cancer risks in populations living near landfill sites in Great Britain. Br J Cancer. 2002; 86(11):1732-6

75. Neuberger JS, Hu SC, Drake KD, Jim R. Potential health impacts of heavymetal exposure at the Tar Creek Superfund site, Ottawa County. Oklahoma Environ Geochem Health. 2009:31(1):47-59. doi:10.1007/s10653-008-9154-0.

76. Benedetti M, Fazzo L, Buzzoni C, Comba P, Magnani C, Fusco M. Incidence of soft tissue sarcomas in an Italian area affected by illegal waste dumping sites. Arch Environ Occup Health. 2015;70(3):154-9. doi:10.1080/19338244.2013.845135.

77. Speer SA, Semenza JC, Kurosaki T, Anton-Culver H. Risk factors for acute myeloid leukemia and multiple myeloma: a combination of GIS and casecontrol studies. J Environ Health. 2002;64(7):9-16.

78. Rogerson PA. Optimal geographic scales for local spatial statistics. Stat Methods Med Res. 2011;20(2):119-29. doi:10.1177/0962280210369039.

79. Carpenter DO, Shen $Y$, Nguyen $T$, Le $L$, Lininger $L L$. Incidence of endocrine disease among residents of New York areas of concern. Environ Health Perspect. 2001;109(Suppl 6):845-51.

80. Huang $X$, Lessner L, Carpenter DO. Exposure to persistent organic pollutants and hypertensive disease. Environ Res. 2006;102(1):101-6. doi:10.1016/j.envres.2005.12.011.

81. Shcherbatykh I, Huang X, Lessner L, Carpenter DO. Hazardous waste sites and stroke in New York State. Environ Health. 2005;29(4):18. doi:10.1186/1476-069X-4-18.

82. Dahlgren J, Takhar H, Anderson-Mahoney P, Kotlerman J, Tarr J, Warshaw R. Cluster of systemic lupus erythematosus (SLE) associated with an oil field waste site: a cross sectional study. Environ Health. 2007;6:8. doi:10.1186/1476-069X-6-8.

83. Sergeev AV, Carpenter DO. Hospitalization rates for coronary heart disease in relation to residence near areas contaminated with persistent organic pollutants and other pollutants. Environ Health Perspect. 2005;113(6):75661. doi:10.1289/ehp.7595.

84. Ala A, Stanca CM, Bu-Ghanim M, Ahmado I, Branch AD, Schiano TD, et al. Increased prevalence of primary biliary cirrhosis near Superfund toxic waste sites. Hepatology. 2006;43(3):525-31. doi:10.1002/hep.21076.

85. Sergeev AV, Carpenter DO. Increase in metabolic syndrome-related hospitalizations in relation to environmental sources of persistent organic pollutants. Int J Environ res and public health. 2011:8(3):762-76. doi:10.3390/ijerph8030762.

86. Gissler M, Laursen TM, Ösby U, Nordentoft M, Wahlbeck K. Patterns in mortality among people with severe mental disorders across birth cohorts: a register-based study of Denmark and Finland in 1982-2006. BMC Public Health. 2013;13:834. doi:10.1186/1471-2458-13-834. 
87. Wright RO, Amarasiriwardena C, Woolf $A D$, Jim R, Bellinger DC. Neuropsychological correlates of hair arsenic, manganese, and cadmium levels in school-age children residing near a hazardous waste site. Neurotoxicology. 2006;27(2):210-6. doi:10.1016/j.neuro.2005.10.001.

88. Eizaguirre-Garcia D, Rodriguez-Andres C, Watt GC. Congenital anomalies in Glasgow between 1982 and 1989 and chromium waste. J Public Health Med. 2000;22(1):54-8.

89. Dodds L, Seviour R. Congenital anomalies and other birth outcomes among infants born to women living near a hazardous waste site in Sydney. Nova Scotia Can J Public Health. 2001;92(5):331-4.

90. Orr M, Bove F, Kaye W, Stone M. Elevated birth defects in racial or ethnic minority children of women living near hazardous waste sites. Int J Hyg Environ Health. 2002;205(1-2):19-27.

91. Morris SE, Thomson AO, Jarup L, de Hoogh C, Briggs DJ, Elliott P. No excess risk of adverse birth outcomes in populations living near special waste landfill sites in Scotland. Scott Med J. 2003;48(4):105-7.

92. Kuehn CM, Mueller BA, Checkoway H, Williams M. Risk of malformations associated with residential proximity to hazardous waste sites in Washington State. Environ Res. 2007;103(3):405-12. doi:10.1016/j.envres.2006.08.008.

93. Elliott P, Richardson S, Abellan JJ, Thomson A, de Hoogh C, Jarup L, et al. Geographic density of landfill sites and risk of congenital anomalies in England. Occup Environ Med. 2009:66(2):81-9. doi:10.1136/oem.2007.038497.

94. Malik S, Schecter A, Caughy M, Fixler DE. Effect of proximity to hazardous waste sites on the development of congenital heart disease. Arch Environ Health. 2004;59(4):177-81. doi:10.3200/AEOH.59.4.177-181.

95. Gilbreath S, Kass PH. Fetal and neonatal deaths and congenital anomalies associated with open dumpsites in Alaska Native villages. Int I Circumpolar Health. 2006;65(2):133-47.

96. Langlois PH, Brender JD, Suarez L, Zhan FB, Mistry JH, Scheuerle A, et al. Maternal residential proximity to waste sites and industrial facilities and conotruncal heart defects in offspring. Paediatr Perinat Epidemiol. 2009; 23(4):321-31. doi:10.1111/j.1365-3016.2009.01045.x.

97. Brender JD, Zhan FB, Suarez L, Langlois PH, Moody K. Maternal residentia proximity to waste sites and industrial facilities and oral clefts in offspring. J Occup Environ Med. 2006;48(6):565-72. doi:10.1097/01.jom.0000214466.06076.07.

98. Suarez L, Brender JD, Langlois PH, Zhan FB, Moody K. Maternal exposures to hazardous waste sites and industrial facilities and risk of neural tube defects in offspring. Ann Epidemiol. 2007;17(10):772-7. doi:10.1016/j.annepidem.2007.05.005.

99. Vrijheid M, Dolk H, Armstrong B, Abramsky L, Bianchi F, Fazarinc l, et al. Chromosomal congenital anomalies and residence near hazardous waste landfill sites. Lancet. 2002;359(9303):320-2. doi:10.1016/50140-6736(02)07531-1.

100. Jarup L, Morris S, Richardson S, Briggs D, Cobley N, de Hoogh C, et al. Down syndrome in births near landfill sites. Prenat Diagn. 2007;27(13):1191-6. doi:10.1002/pd.1873.

101. Brender JD, Zhan FB, Langlois PH, Suarez L, Scheuerle A. Residential proximity to waste sites and industrial facilities and chromosomal anomalies in offspring. Int J Hyg Environ Health. 2008;211(1-2):50-8. doi:10.1016/j.j.jheh.2007.02.009.

102. Baibergenova A, Kudyakov R, Zdeb M, Carpenter DO. Low birth weight and residential proximity to PCB-contaminated waste sites. Environ Health Perspect. 2003:111(10):1352-7.

103. Morgan OW, Vrijheid M, Dolk H. Risk of low birth weight near EUROHAZCON hazardous waste landfill sites in England. Arch Environ Health. 2004;59(3):149-51. https://doi.org/10.3200/AEOH.59.3.149-151.

104. Castello A, Rio I, Garcia-Perez J, Fernandez-Navarro P, Waller LA, Clennon JA, et al. Adverse birth outcomes in the vicinity of industrial installations in Spain 2004-2008. Environ Sci Pollut Res Int. 2013;20(7):4933-46. doi:10.1007/s11356-012-1444-5.

105. Mueller BA, Kuehn CM, Shapiro-Mendoza CK, Tomashek KM. Fetal deaths and proximity to hazardous waste sites in Washington State. Environ Health Perspect. 2007;115(5):776-80. doi:10.1289/ehp.9750.

\section{Submit your next manuscript to BioMed Central and we will help you at every step:}

- We accept pre-submission inquiries

- Our selector tool helps you to find the most relevant journal

- We provide round the clock customer support

- Convenient online submission

- Thorough peer review

- Inclusion in PubMed and all major indexing services

- Maximum visibility for your research

Submit your manuscript at www.biomedcentral.com/submit
( ) BioMed Central 